\title{
HUBUNGAN TINGKAT PENDIDIKAN, TEMPAT TINGGAL DAN INFORMASI PETUGAS LAPANGAN KELUARGA BERENCANA (PLKB) TERHADAP UNMET NEED KB PADA WANITA KAWIN
}

\section{THE CORRELATION OF EDUCATION LEVEL, RESIDENCE, AND INFORMATION OF FAMILY PLANNING FIELD OFFICERS (PLKB) WITH UNMET NEED FOR FAMILY PLANNING ON MARRIED WOMEN}

\author{
Hanum Kholida Zia \\ BKKBN Provinsi Jawa Timur, \\ Jl. Airlangga No.31-33, Airlangga, Gubeng, Surabaya, Indonesia \\ Alamat Korespondensi: Hanum Kholida Zia \\ Email : kholidazia05@gmail.com
}

\begin{abstract}
:
Family Planning Program has some indicators of success; one of the indicators is unmet needs of family planning services. The success of the unmet need indicator services is the decrease of unmet need to $9.9 \%$ in 2019. In 2012, the number of unmet need for family planning amounted to 11.4\%. This study aims to identify whether there is a correlation of the education level, residence, and information of family planning field officers with unmet needs for family planning in East Java. This research was conducted with a cross-sectional design with the data from the 2012 Indonesian Demographic and Health Survey. There is a correlation of the education level $(p=0.000)$, residence $(p=0.010)$, and information of family planning field officer $(p=0.048)$ with the unmet needs for family planning. The research cocludes that education level, residence, and information from health centre affect the unmet need for family planning.
\end{abstract}

Keywords: unmet need, married women, family planning, East Java

ABSTRAK:

Keluarga Berencana memiliki beberapa indikator keberhasilan salah satunya indikator unmet need pelayanan $\mathrm{KB}$. Keberhasilan indikator unmet need $\mathrm{KB}$ adalah menurunnya angka unmet need $\mathrm{KB}$ sehingga menjadi $9,9 \%$ pada tahun 2019. Tahun 2012 angka unmet need KB masih sebesar 11,4\%. Tujuan penelitian ini mengetahui apakah terdapat hubungan antara tingkat pendidikan, tempat tinggal dan informasi PLKB terhadap unmet need KB di Jawa Timur. Penelitian ini dilaksanakan dengan rancangan cross sectional. Penelitian ini menggunakan data hasil Survei Demografi dan Kesehatan Indonesia (SDKI) tahun 2012. Daftar pertanyaan yang digunakan yaitu daftar pertanyaan wanita. Hasil penelitian ini menunjukkan bahwa ada hubungan antara tingkat pendidikan $(p=0,000)$, tempat tinggal $(p=0,010)$ dan informasi PLKB $(p=0,048)$ dengan unmet need KB. Kesimpulan penelitian ini adalah tingkat pendidikan, tempat tinggal dan informasi PLKB mempengaruhi kejadian unmet need $\mathrm{KB}$.

Kata kunci: unmet need KB, wanita kawin, keluarga berencana, Jawa Timur

\section{PENDAHULUAN}

Menurut hasil Survei Sosial Ekonomi Nasional (SUSENAS 2010), dalam waktu 10 tahun terakhir, penduduk Indonesia telah meningkat sebanyak 30 juta jiwa. Hal ini perlu menjadi perhatian karena Negara Indonesia saat ini menempati peringkat ke 4 (empat) Negara dengan jumlah penduduk tertinggi di dunia setelah China, India dan Amerika Serikat. Salah satu penyebab tingginya peningkatan penduduk di Indonesia adalah meningkatnya laju pertumbuhan penduduk Indonesia. Laju pertumbuhan penduduk Indonesia meningkat dari $1,45 \%$ pada periode tahun 1990-2000 menjadi 1,49\% pada priode tahun 2000-2010 (BPS, 2010).

Pemerintah telah membuat berbagai program untuk menanggulangi pertumbuhan penduduk yang terus meningkat, salah satunya melalui program Keluarga Berencana (KB). Keluarga Berencana (KB) dengan salah satu indikatornya yakni unmet need pelayanan KB, masuk dalam Sustainable 
Development Goals (SDGs). Unmet need KB tertuang dalam SDGs tujuan 5 target 5.6. SDGs tujuan 5 adalah menjamin akses universal terhadap kesehatan seksual dan reproduksi, dan hak reproduksi seperti yang telah disepakati sesuai dengan Programme of Action of the International Conference on Population and Development and the Beijing Platform serta dokumen-dokumen hasil reviu dari konferensi-konferensi tersebut. Target yang ditetapkan untuk indikator unmet need $\mathrm{KB}$ adalah menurunnya unmet need kebutuhan ber-KB pada tahun 2019 menjadi 9,9\% (BAPPENAS, 2017).

Persentase unmet need sudah menurun pesat selama kurang lebih 20 tahun dari tahun 1991 hingga tahun 2012 menurut SDKI 2012. Penurunan unmet need $\mathrm{KB}$ sebesar $3,8 \%$, dari $17,0 \%$ pada tahun 1991 menjadi 13,2\% pada tahun 2002. Kurun waktu 10 tahun yakni dari tahun 2002 hingga tahun 2012 unmet need $\mathrm{KB}$ hanya turun $1,6 \%$. Unmet need $\mathrm{KB}$ sebesar pada tahun 2002 sebesar 13,2\% menurunsebesar $0,1 \%$ menjadi $13,1 \%$ pada tahun 2007 dan pada tahun 2012 turun sebesar 1,7\% menjadi 11,4\% (BPS, 2013).

Unmet need $\mathrm{KB}$ pada wanita kawin di Indonesia yang masih mencapai angka $11,4 \%$ belum memenuhi target unmet need KB SDGs sebesar 9,9 \%. Jawa Timur termasuk salah satu provinsi yang menyumbangkan angkat unmet need $\mathrm{KB}$ tertinggi di Indonesia yakni 10,1\% (BPS, 2010). Masih tingginya unmet need KB ini patut diduga berkontribusi terhadap landainya penurunan Angka Kematian Ibu (AKI) dimana program KB merupakan salah satu upaya penurunan AKI di bagian hulu. AKI dapat disebabkan oleh terjadinya kehamilan yang tidak diinginkan pada ibu. Kehamilan yang tidak diinginkan pada ibu dapat mendorong perilaku mencari pelayanan kesehatan yang tidak aman seperti aborsi (KEMENKES 2013).

Unmet need $\mathrm{KB}$ adalah kelompok wanita kawin yang aktif secara seksual namun tidak menggunakan metode kontrasespsi apapun dan mereka tidak menginginkan anak baik untuk penjarangan maupun untuk pencegahan (Bradley et al, 2012). Angka unmet need $\mathrm{KB}$ yang tinggi akan meningkatkan risiko kehamilan bagi wanita kawin, hal ini akan meningkatkan risiko terjadinya kematian ibu dan bayi. Kematian ibu dan bayi dapat dicegah dengan upaya pemenuhan kebutuhan $\mathrm{KB}$, sehingga memperkecil risiko terjadinya kehamilan yang tidak diinginkan sehingga dapat mencegah terjadinya aborsi tidak aman dan persalinan yang berisiko (Ojaaka, 2008)

Masalah unmet need $\mathrm{KB}$ menandakan terdapat kesenjangan antara tujuan reproduksi dengan perilaku kontrasepsi mereka. Hal ini artinya wanita memiliki keinginan untuk menghindari terjadinya kehamilan tetapi tidak melakukan tindakan yang dapat mencegah kehamilan. Banyak aspek yang melatar belakangi kondisi ini, seperti ketidaknyamanan, keterbatasan atau ketersediaan dan harga (Listianingsih et al, 2016). Menurut SDKI 2012, ada beberapa faktor yang menyebabkan individu tidak menggunakan metode atau alat KB. Alasan yang paling banyak adalah alasan yang berkaitan dengan kesuburan meliputi pramenopause dan histerektomi, keinginan untuk memiliki banyak anak, efek samping dari kontrasepsi yang pernah digunakan dan kekhawatiran terhadap efek samping dari kontrasepsi yang akan diguanakan. Alasan pria tidak berKB karena berkaitan dengan kesuburan dan terkait dengan alat/cara KB. Alasan lain responden yang menentang memakai kontrasepsi seperti individu menolak, suami/pasangan menolak, orang lain menolak, larangan agama, kurang pengetahuan baik mengenai alat, cara ataupun sumber KB, jarak yang jauh dari tempat pelayanan $\mathrm{KB}$, biaya kontrasepsi terlalu mahal, dan merasa tidak nyaman (BPS,2013).

Fenomena unmet need $\mathrm{KB}$ bersifat multidimensional karena dipengaruhi berbagai faktor, seperti karakteristik demografi, sosial ekonomi, sikap, dan akses pelayanan. Secara umum, unmet 
need $\mathrm{KB}$ banyak terjadi pada perempuan yang menghadapi hambatan keuangan, pendidikan, geografis, dan sosial. Kondisi sosial ekonomi yang kurang menguntungkan menjadi penyebab tingginya unmet need, tetapi wilayah lain dengan kondisi sosial ekonomi masyarakat yang memadai juga memiliki tingkat unmet need yang tinggi. Faktor yang melatar belakangi kedua hal tersebut jelas berbeda. Pendidikan dan kondisi ekonomi merupakan variabel penting untuk menjelaskan terjadinya unmet need $\mathrm{KB}$ pada wanita kawin (Listianingsih et al, 2016). Berdasarkan masalah yang ada, tujuan dari penelitian ini adalah ingin mengetahui apakah terdapat hubungan antara tingkat pendidikan, tempat tinggal wanita kawin dan informasi PLKB yang melakukan kunjungan ke wanita kawin dengan kejadian unmet need $\mathrm{KB}$ di Jawa Timur.

\section{METODE PENELITIAN}

Penelitian ini dilakukan di Kota Surabaya. Penelitian ini merupakan analisis data sekunder dengan menggunakan data SDKI 2012 yang diakses melalui website DHS (Demographic and health Surveys). Jenis penelitian yang digunakan adalah penelitian non reaktif yaitu jenis penelitian untuk data sekunder. Berdasarkan sifat penelitiannya, penelitian ini bersifat analitik, karena bertujuan untuk menganalisis permasalahan yang diteliti dan merupakan penelitian observasional dimana penelitian menggunakan data sekunder untuk dilakukan pengamatan terhadap data-data yang sudah tersedia.

Penelitian ini menggunakan desain penelitian cross sectional yaitu desain penelitian yang mengukur suatu kejadian pada waktu tertentu dan mengukur variabel yang diteliti bersamaan.

Daftar pertanyaan yang digunakan pada penelitian ini yaitu daftar pertanyaan wanita. Populasi pada penelitian ini adalah wanita kawin dengan rentan usia 15 sampai 49 tahun yang di Provinsi Jawa Timur pada tahun 2012. Setelah dilakukan penyaringan, maka sampel yang didapat sebesar 5.753 orang. Pada penelitian ini, hal yang ingin diteliti adalah kejadian unmet need $\mathrm{KB}$ pada wanita kawin yang telah menikah. Faktor yang ingin diteliti adalah tingkat pendidikan, tempat tinggal dan informasi PLKB yang melakukan kunjungan rumah kepada wanita kawin. Pengolahan data dalam penelitian ini, apabila terdapat data yang missing pada variabel dependen, maka data tersebut akan dihapus. Analisis data dilakukan dengan deskriptif dan analitik. Analisis deskriptif data pada penelitian ini dilakukan dengan menggunakan untuk mengetahui distribusi frekuensi variabel yang diteliti. Analisis data dilakukan dengan uji chi square. Uji chi square dilakukan untuk mengetahui apakah ada hubungan antara tingkat pendidikan, tempat tinggal dan informasi PLKB terhadap unmet need $\mathrm{KB}$ pada wanita kawin. Penelitian ini telah memperoleh keterangan lolos kaji etik dari Komisi Etik FKM No : 130-KEPK.

\section{HASIL}

\section{Gambaran Karateristik Wanita kawin.}

Wanita kawin mempunyai umur termuda 15 tahun dan umur tertua 49 tahun. Umur wanita kawin dikelompokkan menjadi 7 kelompok umur dengan rentan umur 5 tahun. Tabel 1 menunjukkan umur wanita kawin paling banyak pada kategori umur 30-34 tahun (18,6 \%), selanjutnya diikuti dengan wanita kawin dengan kategori umur 35-39 tahun (17,8). Wanita kawin yang berumur 20 sampai 24 tahun sebanyak 689 orang (12\%). Wanita kawin yang berumur 25 sampai 29 tahun sebanyak 956 orang $(16,6 \%)$. Wanita kawin yang berumur 15 sampai 19 tahun hanya 131 orang $(2,3 \%)$. Wanita kawin dengan umur diatas 35 tahun menjadi wanita kawin terbanyak pada penelitian ini. 
Tabel 1.Distribusi Frekuensi Umur, Jumlah Anak Hidup, Jumlah Anak Ideal, Tingkat pendidikan dan Status PekerjaanWanita Kawin di Jawa Timur

\begin{tabular}{lll}
\hline $\begin{array}{l}\text { Karateristik } \\
\text { Wanita } \\
\text { kawin }\end{array}$ & Frekuensi & $\begin{array}{l}\text { Persentase } \\
(\%)\end{array}$ \\
\hline Umur & & \\
\hline $15-19$ & 131 & 2,3 \\
\hline $20-24$ & 689 & 12,0 \\
\hline $25-29$ & 956 & 16,6 \\
\hline $30-34$ & 1.068 & 18,6 \\
\hline $35-39$ & 1.022 & 17,8 \\
\hline $40-44$ & 992 & 17,2 \\
\hline $45-49$ & 896 & 15,6 \\
\hline Total & 5.753 & 100 \\
\hline
\end{tabular}

\section{Jumlah Anak}

Hidup

\begin{tabular}{lll}
\hline Belum ada & 480 & 8,3 \\
\hline 1-3 orang & 4.861 & 84,5 \\
\hline$>3$ orang & 412 & 7,3 \\
\hline Total & 5.753 & 100 \\
\hline
\end{tabular}

\section{Jumlah Anak}

Ideal

\begin{tabular}{lll}
\hline $\begin{array}{l}\text { Tidak punya } \\
\text { anak }\end{array}$ & 15 & 0,3 \\
\hline $1-2$ & 4.169 & 72,5 \\
\hline$>2$ & 1.349 & 23,4 \\
\hline Total & 5.753 & 100 \\
\hline $\begin{array}{l}\text { Tingkat } \\
\text { Pendidikan }\end{array}$ & & \\
\hline $\begin{array}{l}\text { Tidak } \\
\text { sekolah }\end{array}$ & 296 & 5,1 \\
\hline $\begin{array}{l}\text { Pendidikan } \\
\text { dasar }\end{array}$ & 2.438 & 42,4 \\
\hline $\begin{array}{l}\text { Pendidikan } \\
\text { menengah }\end{array}$ & 2.538 & 44,1 \\
\hline $\begin{array}{l}\text { Pendidikan } \\
\text { tinggi }\end{array}$ & 482 & 8,4 \\
\hline Total & 5.753 & 100 \\
\hline $\begin{array}{l}\text { Status } \\
\text { Pekerjaan }\end{array}$ & & \\
\hline $\begin{array}{l}\text { Tidak } \\
\text { Bekerja }\end{array}$ & 1.849 & 22,1 \\
\hline Bekerja & 3.894 & 77,9 \\
\hline Total & 5.753 & 100 \\
\hline Sube Pengol & & \\
\hline
\end{tabular}

Sumber: Pengolahan Data SDKI 2012
Tabel 1 menunjukkan bahwa jumlah anak yang dimiliki wanita kawin terbanyak adalah 1-3 orang anak $(84,5 \%)$. Jumlah wanita kawin yang tidak memiliki anak sebesar 8,3\% dan wanita kawin yang memiliki anak lebih dari 3 orang sebesar 7,3 \%. Tabel 1 menunjukkan bawa anak ideal yang ingin dimiliki oleh wanita kawin berjumlah 1-2 orang anak sebesar $72,5 \%$. Persentase wanita kawin yang ingin memiliki anak lebih dari 2 sebesar $23,4 \%$. Tingkat pendidikan wanita kawin paling banyak adalah pendidikan menengah $(44,1 \%)$. Terdapat wanita kawin yang tidak bersekolah $(5,1 \%)$, tingkat pendidikan dasar $(42,4 \%)$ dan tingkat pendidikan tingggi $(8,4 \%)$. Tabel 1 menunjukkan bahwa mayoritas wanita kawin yang bekerja sebesar $77,9 \%$. Wanita kawin yang tidak bekerja sebesar $22,1 \%$.

Tabel 2.Distribusi Frekuensi Tingkat Kesejahteraan Wanita Kawin di Jawa Timur

\begin{tabular}{lll}
\hline $\begin{array}{l}\text { Tingkat } \\
\text { Kesejahteraan }\end{array}$ & Frekuensi & $\begin{array}{l}\text { Persentase } \\
(\boldsymbol{\%})\end{array}$ \\
\hline $\begin{array}{l}\text { Terbawah } \\
\begin{array}{l}\text { Menengah } \\
\text { bawah }\end{array}\end{array}$ & 520 & 9,0 \\
\hline Menengah & 1.195 & 20,8 \\
\hline Menengah atas & 1.464 & 24,8 \\
\hline Teratas & 1.145 & 19,9 \\
\hline Total & 5.753 & 100 \\
\hline
\end{tabular}

Sumber :Pengolahan Data SDKI 2012

Tabel 2 menunjukkan wanita kawin dengan tingkat kesejahteraan terbanyak adalah wanita kawin dengan tingkat kesejahteraan menengah atas sebesar $25,4 \%$. Wanita kawin dengan tingkat kesejahteraan terbawah sebesar 9,0\%. Wanita kawin dengan tingkat kesejahteraan teratas sebesar $19,9 \%$. Tabel 3 menunjukkan bahwa wanita kawin yang tinggal di daerah perkotaan sebanyak 2.725 orang $(47,4 \%)$. Jumlah wanita kawin yang tinggal di daerah perkotaan hampir sama dengan jumlah wanita kawin yang tinggal di daerah perdesaan sebanyak 3.028 orang 
$(52,6 \%)$.Distribusi frekuensi tempat tinggal wanita kawin dapat dilihat pada Tabel 3.

Tabel 3.Distribusi Frekuensi Tempat Tinggal Wanita Kawin di Jawa Timur.

\begin{tabular}{lll}
\hline $\begin{array}{l}\text { Tempat } \\
\text { tinggal }\end{array}$ & Frekuensi & $\begin{array}{l}\text { Persentase } \\
(\%)\end{array}$ \\
\hline Kota & 2.725 & 47,4 \\
\hline Desa & 3.028 & 52,6 \\
\hline Total & 5.753 & 100 \\
\hline
\end{tabular}

Sumber :Pengolahan Data SDKI 2012

Tabel 4.Distribusi Frekuensi Informasi PLKB mengenai KB di Jawa Timur

\begin{tabular}{lll}
\hline $\begin{array}{l}\text { Informasi } \\
\text { PLKB }\end{array}$ & Frekuensi & $\begin{array}{l}\text { Persentase } \\
(\boldsymbol{\%})\end{array}$ \\
\hline Ya & 618 & 10,8 \\
\hline Tidak & 5.131 & 89,2 \\
\hline Total & 5.749 & 100 \\
\hline S
\end{tabular}

Sumber : Pengolahan Data SDKI 2012

Tabel 4 menunjukkan bahwa mayoritas $(89,2 \%)$ wanita kawin tidak mendapatkan informasi mengenai KB dari PLKB melalui kunjungan petugas ke wanita kawin. Wanita kawin yang mendapatkan informasi $\mathrm{KB}$ melalui kunjungan PLKB sebesar 10,8\%.

\section{Gambaran Kejadian Unmet Need KB.}

Distribusi wanita kawin berdasarkan kejadian unmet need $\mathrm{KB}$ di dapat dilihat pada Tabel 5.

Tabel 5.Distribusi Frekuensi Unmet Need KB pada Wanita Kawin di Jawa Timur

\begin{tabular}{lll}
\hline $\begin{array}{l}\text { Unmet Need } \\
\text { KB }\end{array}$ & Frekuensi & $\begin{array}{l}\text { Persentase } \\
(\boldsymbol{\%})\end{array}$ \\
\hline Ya & 582 & 10,1 \\
\hline Tidak & 5.171 & 89,9 \\
\hline Total & 5.753 & 100,0 \\
\hline Sin
\end{tabular}

Sumber:Pengolahan Data SDKI 2012
Hasil penelitian pada Tabel 5 menunjukkan bahwa dari 5.753 wanita kawin, wanita kawin yang berstatus menikah, sebagaian besar termasuk kelompok yang bukan unmet need $\mathrm{KB}$ yang berjumlah 5.171 orang $(89,9 \%)$ yang masuk dalam kelompok unmet need $\mathrm{KB}$ berjumlah 582 orang $(10,1 \%)$.

\section{Hubungan Tingkat pendidikan, Tempat Tinggal dan Informasi PLKB terhadap Unmet Need KB di Jawa Timur}

Hasil tabulasi silang pada Tabel 6 menunjukkan wanita kawin yang tidak bersekolah, prosentase unmet need $\mathrm{KB}$ $(6,4 \%)$ lebih kecil dibandingkan yang tidak unmet need KB $(93,6 \%)$. Sama halnya dengan wanita kawin dengan pendidikan dasar yang unmet need KB $(12,4 \%)$ lebih kecil dibandingkan yang tidak unmet need KB (87,6\%). Wanita kawin dengan pendidikan menengah yang unmet need KB $(11,2 \%)$ lebih kecil dibandingkan yang tidak unmet need $\mathrm{KB}(88,8 \%)$. Wanita kawin dengan pendidikan tinggi yang unmet need $\mathrm{KB}(10,1 \%)$ lebih kecil dibandingkan dengan yang tidak unmet need KB $(89,9 \%)$. Hasil dari Tabel 6 dapat disimpulkan bahwa wanita kawin yang berpendidikan menengah lebih banyak berperilaku unmet need $\mathrm{KB}$ dibandingkan dengan wanita kawin yang berpendidikan lainnya. Hasil uji chi square yang diperoleh adalah $p=0,000$, sehingga terdapat hubungan antara tingkat pendidikan dengan unmet need $\mathrm{KB}$ pada wanita kawin di Jawa Timur.

Hasil tabulasi silang pada Tabel 6 menunjukkan wanita kawin dengan kejadian unmet need $\mathrm{KB}$ menurut daerah tempat tinggal mempunyai hasil sebagai berikut : untuk wanita kawin yang tinggal di daerah perkotaan yang unmet need $\mathrm{KB}$ $(11,2 \%)$ lebih kecil dari yang tidak unmet need KB $(88,8 \%)$. Wanita kawin yang tinggal di daerah perdesaan unmet need $\mathrm{KB}$ sebesar 9,1\% lebih kecil dari wanita yang tidak unmet need KB sebesar 90,9\%.

Hasil dari Tabel 6 menunjukkan wanita kawin yang tinggal di daerah 
perkotaan perilaku unmet need $\mathrm{KB}$ lebih tinggi daripada wanita kawin di daerah perdesaan. Hasil uji chi square yang diperoleh adalah $p=0,010$, sehingga dapat disimpulkan terdapat hubungan antara tempat tinggal dengan kejadian unmet need $\mathrm{KB}$ pada wanita kawin di Jawa Timur. Hasil tabulasi silang pada Tabel 6 menunjukkan wanita kawin dengan kejadian unmet need $\mathrm{KB}$ menurut informasi yang didapatkan dari petugas lapangan KB. Kejadian unmet need $\mathrm{KB}$ dengan informasi PLKB mempunyai hasil sebagai berikut : untuk wanita kawin yang mendapatkan informasi PLKB yang unmet need $\mathrm{KB}$ yakni sebesar 7,7\% lebih kecil dari tidak unmet need $\mathrm{KB}$ yang sebesar 92,3\%. Wanita kawin yang tidak mendapatkan informasi PLKB yang unmet need $\mathrm{KB}$ yakni sebesar 10,7\% juga lebih kecil daripada wanita yang tidak unmet need $\mathrm{KB}$ yakni sebesar $89,9 \%$.

Hasil dari Tabel 6 menunjukkan wanita kawin yang tidak mendapatkan informasi PLKB perilaku unmet need KB lebih tinggi daripada wanita kawin yang mendapatkan informasi PLKB. Hasil uji chi square sebesar $p=0,048$, sehingga dapat disimpulkan bahwa terdapat hubungan antara informasi PLKB dengan kejadian unmet need $\mathrm{KB}$ pada wanita kawin di Jawa Timur.

Tabel 6. Tabulasi Silang antara Tingkat Pendidikan, Tempat Tinggal dan Informasi PLKB dengan Unmet Need KB di Jawa Timur.

\begin{tabular}{|c|c|c|c|}
\hline \multirow{3}{*}{$\begin{array}{l}\text { Tingkat } \\
\text { Pendidikan }\end{array}$} & \multicolumn{3}{|c|}{ Unmet need KB V } \\
\hline & \multicolumn{2}{|c|}{ Unmet Need } & Tid \\
\hline & n & $\%$ & $\mathbf{n}$ \\
\hline Tidak sekolah & 19 & 6,4 & 27 \\
\hline Pendidikan dasar & 301 & 12,4 & 2.1 \\
\hline $\begin{array}{l}\text { Pendidikan } \\
\text { menengah }\end{array}$ & 208 & 8,2 & 2. \\
\hline Pendidikan tinggi & 54 & 11,2 & 429 \\
\hline \multirow[t]{3}{*}{ Tempat Tinggal } & \multicolumn{3}{|c|}{ Unmet need KB V } \\
\hline & \multicolumn{2}{|c|}{ Unmet Need } & Tid \\
\hline & n & $\%$ & n \\
\hline Kota & 305 & 11,2 & 2.4 \\
\hline Desa & 277 & 9,1 & 1.9 \\
\hline \multirow{3}{*}{$\begin{array}{l}\text { Informasi } \\
\text { PLKB }\end{array}$} & \multicolumn{3}{|c|}{ Unmet need KB V } \\
\hline & \multicolumn{2}{|c|}{ Unmet Need } & Tid \\
\hline & n & $\%$ & $\mathbf{n}$ \\
\hline Ya & 54 & 7,7 & 649 \\
\hline Tidak & 223 & 10,7 & 1.9 \\
\hline \multicolumn{4}{|c|}{ Sumber : Pengolahan Data SDKI 2012} \\
\hline \multicolumn{4}{|l|}{ PEMBAHASAN } \\
\hline \multicolumn{4}{|l|}{ Unmet Need KB } \\
\hline \multicolumn{4}{|c|}{$\begin{array}{l}\text { Hasil penelitian menunjukkan dari } \\
5753 \text { wanita kawin, terhadap kejadian } \\
\text { unmet need KB sebesar } 10,1 \% \text {, lebih kecil } \\
\text { dibandingkan yang tidak unmet need KB. } \\
\text { Hasil penelitian ini sesuai dengan hasil } \\
\text { penelitian yang dimuat pada SDKI } 2012 \text {. }\end{array}$} \\
\hline
\end{tabular}

p value

$\begin{array}{llll}276 & 93,6 & 295 & 100\end{array}$

\begin{tabular}{llll}
2.136 & 92,4 & 2.437 & 100 \\
\hline 330 & 91,8 & 2.538 & 100
\end{tabular}

$483 \quad 100$

\section{Total}

p value

n $\%$ n $\quad$ \%

$2.725 \quad 100$

$3.028 \quad 100$

0,010

$\begin{array}{ll}2.420 & 88,8 \\ 1.963 & 90,9\end{array}$

Total

Kawin 
belum mencapai target yakni masih 10,1\% (SDKI, 2012).

Faktor yang mempengaruhi unmet need KB antara lain pendidikan, pekerjaan, umur, pengalaman, kebudayaan dan informasi. Secara rinci dapat diuraikan sebagai berikut: pendidikan dapat mempengaruhi seseorang termasuk juga perilaku seseorang akan pola hidup terutama dalam memotivasi untuk berperan serta dalam pembangunan. Makin tinggi tingkat pendidikan seseorang, makin mudah menerima informasi sehingga makin banyak pula pengetahuan yang dimiliki. Banyaknya wanita kawin yang mempunyai pendidikan SMA dan lebih tinggi (Tabel 1) akan mempermudah dalam memahami materi tentang $\mathrm{KB}$ dan dapat meningkatkan pengetahuan tentang $\mathrm{KB}$.

\section{Hubungan Antara Unmet Need KB dengan Tingkat Pendidikan Wanita kawin di Jawa Timur}

Hasil analisis chi square menunjukkan bahwa tingkat pendidikan mempunyai signifikansi sebesar 0,010 yang artinya ada hubungan antara tingkat pendidikan dengan kejadian unmet need KB di Jawa Timur. Penelitian ini didukung dengan penelitian Nurinda et al (2013) yang menyatakan bahwa hasil gambaran unmet need $\mathrm{KB}$ menurut pendidikan menunjukkan bahwa unmet need $\mathrm{KB}$ berada banyak pada wanita dengan pendidikan rendah. Pendidikan rendah pada Provinsi Nusa Tenggara Timur cenderung 1,404 kali lebih tinggi untuk mengalami unmet need KB dibandingkan dengan wanita yang berpendidikan tinggi. Wanita yang berpendidikan rendah di Provinsi Yogyakarta 1,125 kali lebih tinggi risiko mengalami unmet need $\mathrm{KB}$ dibandingkan dengan wanita yang berpendidikan tinggi.

Penelitian ini sesuai dengan penelitian Ariyanti (2016) yang menyatakan bahwa tingkat pendidikan ibu mempunyai pengaruh terhadap unmet need KB. Pendidikan dapat mempengaruhi unmet need $\mathrm{KB}$ karena semakin tinggi pendidikan seseorang maka informasi yang diperoleh akan semakin banyak. Seseorang yang berpendidikan tinggi akan lebih mudah menerima informasi baru termasuk informasi mengenai alat kontrasepsi yang dapat digunakan. Penelitian ini diperkuat dengan penelitian Porouw (2014) yang menyatakan bahwa ibu yang berpendidikan rendah 0,372 kali mengalami unmet need KB dibandingkan ibu yang berpendidikan tinggi. Porouw menganggap ibu yang berpendidikan rendah memiliki pemahaman yang kurang mengenai informasi yang didapatkannya termasuk informasi mengenai keluarga berencana, sehingga meningkatkan peluang ibu untuk unmet need $\mathrm{KB}$.

Penelitian Katulistiwa et al (2013) menyatakan wanita yang berpendidikan SD berisiko 1,6 kali lebih besar untuk mengalami unmet need $\mathrm{KB}$ dibandingkan dengan wanita yang berpendidikan SMPSMA dan perguruan tinggi. Wanita yang tidak sekolah berisiko 1,2 kali lebih besar untuk mengalami unmet need $\mathrm{KB}$ dibandingkan dengan wanita yang berpendidikan SMP-SMA dan perguruan tinggi. Hasil penelitian ini tidak sesuai dengan Sariyati et al (2015) yang menyatakan bahwa pendidikan tidak mempunyai hubungan dengan perilaku unmet need KB pada wanita kawin $(p=0,057)$. Pendidikan wanita kawin yang semakin tinggi membuat kemungkinan seseorang untuk unmet need $\mathrm{KB}$ semakin besar. Hal ini dikarenakan mereka sudah mengetahui bagaimana mencegah kehamilan dengan cara selain menggunakan alat kontrasepsi dan dengan cara alami sehingga mereka tidak bersedia menggunakan kontrasepsi modern ataupun kontrasepsi dengan menggunakan alat. Pengalaman negatif dari efek samping penggunaan alat kontrasepsi dan pengalaman pernah mengalami kegagalan menggunakan alat kontrasepsi membuat seseorang tidak menggunakan alat kontrasepsi, sehingga meskipun pendidikan seseorang tinggi tetap memungkinkan terjadinya unmet need $\mathrm{KB}$. 
Fadhila et al (2016) menyatakan bahwa tidak terdapat hubungan antara tingkat pendidikan dan unmet need $\mathrm{KB}$ $(p=1,000)$. Hal ini dapat terjadi di perkotaan dengan kemunginan interaksi antara orang berpendidikan tinggi dengan orang berpendidikan rendah cukup besar, sehingga perilaku dan pola hidup hidup mereka tidak jauh berbeda. Meskipun demikian wanita kawin yang berpendidikan rendah lebih berpeluang unmet need $\mathrm{KB}$ dibandingkan dengan wanita yang berpendidikan tinggi.

Kurniawati (2014) menyatakan bahwa faktor pendidikan tidak cukup berpengaruh terhadap alasan wanita kawin untuk tidak ikut serta dalam program $\mathrm{KB}$, hal ini dikarenakan, informasi mengenai KB dapat diketahui dimana saja dan dari siapa saja, seperti Bidan Desa. Kejadian unmet need $\mathrm{KB}$ yang seimbang antara wanita kawin yang berpendidikan tinggi dengan wanita kawin yang berpendidikan rendah dipengaruhi oleh banyak faktor antara lain akses terhadap informasi yang semakin mudah dan kesadaran wanita kawin untuk mencari informasi dari semua sumber.

\section{Hubungan Antara Unmet Need KB dengan Tempat Tinggal Wanita kawin di Jawa Timur}

Hasil analisis chi square menunjukkan bahwa tempat tinggal memiliki nilai signifikansi sebesar 0,010 yang artinya ada hubungan antara tempat tinggal dengan kejadian unmet need $\mathrm{KB}$ di Jawa Timur. Hasil penelitian ini sesuai dengan penelitian yang dilakukan Putri et al (2013) yang menyatakan bahwa tempat tinggal mempengaruhi kejadian unmet need KB. Penduduk yang tinggal di desa lebih besar kemungkinan untuk mengalami unmet need $\mathrm{KB}$ dikarenakan masyarakat di desa kurang terpapar informasi baik dari media massa ataupun petugas lapangan KB.

Hasil penelitian ini sesuai dengan hasil penelitian Adam (2010) yang menyatakan bahwa peserta $\mathrm{KB}$ di daerah perkotaan peluang untuk mendapatkan pelayanan KB lebih besar daripada peserta KB di daerah perdesaan. Pelayanan KB di daerah perkotaan mempunyai kualitas yang lebih baik daripada di daerah perdesaan. Hasil penelitian Listianingsih et al (2016) menyatakan bahwa wanita kawin yang tinggal di desa kemungkinan lebih kecil mengalami unmet need $\mathrm{KB}$ daripada yang tinggal dikota. Daerah tempat tinggal berhubungan dengan akses untuk mendapatkan pelayanan KB. Hasil Penelitian ini sesuai dengan penelitian $\mathrm{Zia}$ (2017) yang menyatakan bahwa tempat tinggal berpengaruh terhadap kejadian unmet need $\mathrm{KB}$. Hasil penelitian ini tidak sesuai dengan penelitian Ariyanti (2016) yang menyatakan bahwa daerah tempat tinggal tidak memiliki pengaruh terhadap unmet need $\mathrm{KB}$. Umumnya akses pelayanan $\mathrm{KB}$ di daerah perdesaan lebih sulit, namun saat ini mulai dibangun klinik $\mathrm{KB}$ di daerah perdesaan dan dibuat berbagai program oleh BKKBN untuk meningkatkan angka keikutsertaan $\mathrm{KB}$ terutama untuk daerah pedesaan.

Menurut Katulistiwa et al (2013), jarak pelayanan $\mathrm{KB}$ dengan tempat tinggal mempengaruhi kejadian unmet need $\mathrm{KB}$. Tempat tinggal yang jauh dari tempat pelayanan KB dapat memperbesar hambatan yang mempengaruhi kepesertaan KB pada aseptor KB. Hasil penelitian menunjukkan tempat tinggal berhubungan dengan unmet need $\mathrm{KB}$ pada wanita kawin. Hasil penelitian menunjukkan bahwa unmet need $\mathrm{KB}$ pada wanita kawin yang bertempat tinggal di daerah perkotaan lebih tinggi daripada wanita kawin yang tinggal di daerah perdesaan.

\section{Hubungan antara Unmet Need KB dengan Informasi PLKB kepada Wanita kawin di Jawa Timur}

Hasil analisis chi square menunjukkan bahwa informasi PLKB yang melakukan kunjungan kepada wanita kawin memiliki nilai signifikansi sebesar 0,048 yang artinya ada hubungan antara informasi PLKB dengan kejadian unmet 
need $\mathrm{KB}$ di Jawa Timur. Hasil penelitian sesuai dengan penelitian Ulsafitri et al (2014) yang menyatakan bahwa ada hubungan antara informasi PLKB dengan kejadian unmet need $\mathrm{KB}$ pada wanita kawin dengan nilai signifikansinya $p=0,000$.

Suseno (2011), menyatakan salah satu hal yang harus diperhatikan oleh layanan kesehatan adalah kompetensi petugas kesehatan. Kompetensi petugas kesehatan dapat mempengaruhi informasi yang diberikan kepada aseptor KB. Informasi mengenai $\mathrm{KB}$ yang didapatkan dapat meningkatkan pengetahuan masyarakat mengenai cara atau alat kontrasepsi dan meningkatkan penerimaan metode kontrasepsi yang efektif dengan risiko rendah.

Hasil penelitian Putriet al (2013) menunjukkan bahwa persentase responden yang mengalami unmet need $\mathrm{KB}$ antara yang mendapatkan kunjungan dari petugas lapangan KB dengan yang tidak mendapatkan kunjungan dari petugas lapangan $\mathrm{KB}$ tidak jauh berbeda, hanya terdapat selisih sebanyak $1 \%$. Hardiyanto, Sekertaris Utama BKKBN Pusat pada tahun 2013 menyebutkan kurangnya jumlah petugas lapangan keluarga berencana (PLKB) mengakibatkan program KB stagnan selama 10 tahun terakhir. Keberadaan PLKB sebenarnya sangat dibutuhkan untuk meningkatkan pengetahuan dan pemahaman masyarakat tentang pentingnya menggunakan alat atau cara kontrasepsi terutama untuk jangka panjang atau MJKB (BKKBN Kepulauan Riau, 2013).

Berdasarkan hasil penelitian, dapat disimpulkan bahwa informasi yang didapatkan wanita kawin dari petugas kesehatan yang berkunjung turut mempengaruhi keputusan untuk unmet need KB. Kompetensi petugas lapangan $\mathrm{KB}$ dapat mempengaruhi informasi yang disampaikan oleh petugas lapangan KB. Informasi PLKB dapat mempengaruhi pemahaman informasi mengenai alat dan cara kontrasepsi pada aseptor $\mathrm{KB}$ yang efektif.

\section{SIMPULAN}

Karateristik wanita kawin yang berstatus menikah menurut SDKI 2012 mayoritas berumur 30-34 tahun. Mayoritas jumlah anak 1-3 orang. Jumlah anak ideal mayoritas wanita kawin 1-2 orang. Tingkat pendidikan paling banyak adalah tingkat pendidikan menengah. Mayoritas wanita kawin bekerja. Tingkat kesejahteraan mayoritas menengah hingga menengah keatas.

Distribusi tempat tinggal antara perkotaan dan perdesaan hampir sama. Informasi yang didapatkan dari PLKB yang berkunjung mayoritas tidak ada, karena mayoritas wanita kawin tidak mendapatkan kunjungan dari petugas lapangan KB. Unmet Need KB di Jawa Timur pada tahun 2012 sebesar 582. Faktor-faktor yang mempengaruhi unmet need $\mathrm{KB}$ pada wanita kawin dalam penelitian ini adalah tingkat pendidikan $(p=0,000)$, tempat tinggal $(p=0,010)$ dan informasi PLKB $(p=0,048)$.

Saran bagi pelaksana program yakni BKKBN adalah membuat program yang dapat mencakup semua tingkat pendidikan wanita kawin. PLKB berperan sangat penting, sehingga disarankan agar PLKB selalu meningkatkan kompetensi yang dimiliki sehingga dapat mengoptimalkan perannya dalam pemberian informasi kepada wanita kawin.

\section{DAFTAR PUSTAKA}

Adam, P., F., 2010. Kajian tentang Prevalensi Kontrasepsi Keluarga Berencana Catatan Kecil Dalam Upaya Pencapaian MDGs 2015 di Maluku. [e-journal].

Ariyanti, M.M., 2016. Pemodelan Regresi Logistik untuk mengetahui Faktor yang Mempengaruhi Unmet Need Keluarga Berencana di Jawa Timur. 
Skripsi. Surabaya: Universitas Airlangga.

BPS. Survei Demografi dan Kesehatan Indonesia (SDKI) 2012. Badan Pusat Statistik, BKKBN, Kementrian Kesehatan, Maccro Calverton Mary Land: Jakarta. 2013.

BAPPENAS. Ringkasan Metadata Indikator Tujuan Pembangunan Berkelanjutab (TPB)/ Sustainable Development Goals (SDGs) Indonesia.mKementerian

Perencanaan Pembangunan Nasional/ Bappenas : Jakarta. 2017.

Bizuneh, Genene, Shiferaw, S., Melkamu, Y., 2008. Unmet Need and Evaluation of Programme Options to Meet Unmet Need for Contraception in Ethiopia, 20002005: Further Analysis of the 2000 and 2005 Ethiopia Demographic and Health Surveys. Calverton, Maryland,

USA: MacroInternational Inc.

BKKBN Kepulauan Riau, 2013. BKKBN Kekurangan PLKB, Program KB Stagnan.

Bradley, S.E.K., Croft, T.N. Fishel, J.D and Westoff, C.F. 2012. Revising Unmet Need for Family Planning. DHS Analytical Studies No. 25. Calverton, Maryland, USA: ICF International.

Fadhila, H.N., Widoyo, R., Elytha, F. 2016. Unmet Need Keluarga Berencana pada Pasangan Usia Subur di Kecamatan Padang Barat Tahun 2015. [e-Journal] Jurnal kesehatan Masyarakat Andalas. Vol10(2): 151-156 [https:// https://doi.org/10.24893/jk ma.10.2.151-156.2016]

Katulistiwa, R., 2014. Determinan Unmet Need KB pada Wanita Menikah di Kecamatan Klabang Kabupaten Bondowoso (Determinants for Family Planning Among Married Women at Klabang Sub District in Bondowoso). [e-journal] Pustaka
Kesehatan Volume 2 No.2 Mei 2014.

Kurniawati, Y., 2014. Analisis FaktorFaktor yang Mempengaruhi Ketidakikutsertaan Pasangan Usia Subur (PUS) dalam Program Keluarga Berencana di Kecamatan Pujud Kabupaten Rokan Hilir. [ejournal] Jom FISIP Volume 1 No. 2 - Oktober2014.pp 1-15.

Listianingsih, U., Sumini., Satiti, S., 2016. Unmet Need: Konsep yang Masih Perlu Diperdebatkan. [e-journal] Jurnal UGM. Volume 24, Nomor 1. Pp 72-90.

Nurinda, A., Herdayati, M., 2013. Hubungan Pendidikan, Pengetahuan KB, dan Otonomi Wanita pada Kejadian Unmet Need (Kebutuhan KB yang Tidak Terpenuhi) di Provinsi Yogyakarta dan NTT Menurut SDKI 2007. [ejournal]

Ojaaka, D., 2008. Trends and Determinants of Unmet Need for Family Planning in Kenya. [e-journal] DHS Working Paper.

Perwakilan BKKBN Jawa Timur., 2017. Evaluasi Program KKBPK: Data Februari 2017. Surabaya.

Porouw, S, H., 2014. Faktor-Faktor yang berhubungan dengan Kebutuhan Keluarga Berencana yang Tidak Terpenuhi (Unmet Need) di Kecamatan Sipatana Kota Gorontalo. [e-Journal]

Putri, M.D., Prasetyo, S., 2013. Kebutuhan KB yang Tidak Terpenuhi (Unmet Need) pada Wanita Menikah 2 Tahun Pascasalin (Analisis Lanjut Data SDKI Tahun 2007). [e-journal]

Sariyati, S., Mulyaningsih, S., Sugiharti, S., 2015. Faktor yang Berhubungan dengan Terjadinya Unmet Need KB pada Pasangan Usia Subur (PUS) di Kota Yogyakarta. [e-journal] Journal Ners and Midwifery Indonesia. [https:// DOI: 10.21927/jnki.2015.3(3).123-128] 
Suseno, R., M. 2011. Faktor-faktor yang Berpengaruh Terhadap Kebutuhan Keluarga Berencana yang Tidak Terpenuhi (Unmet Need for Family Planning) di Kota Kediri. [ejournal] Jurnal Kebidanan Panti Wilaya, vol.2(1).

Ulsafitri, Y. Fastin, N.R., 2014. FaktorFaktor yang Berhubungan dengan Unmet Need KB pada Pasangan Usia Subur (PUS). LPPM Stikes Yarsi.

Katulistiwa, R., Baroya, N., Wati, M.D., 2013. Determinan Unmet Need KB pada Wanita Menikah di Kecamatan Klabang Kabupaten Bondowoso (Determinants for Family Planning Among Married Women at Klabang SubDistrict in Bondowoso). [e-journal]

Kementerian Kesehatan, 2015. Profil Kesehatan Indonesia 2014. Jakarta : Kementerian Kesehatan Republik Indonesia.

Zia, H., K., 2017. Faktor yang Mempengaruhi Unmet Need KB pada Wanita Kawin. Skripsi. Surabaya : Universitas Airlangga. 